\title{
Calciphylaxis, a diagnostic and therapeutic challenge: report of a successful case
}

Calcifilaxia, desafio diagnóstico e terapêutico: relato de um caso bem sucedido

\author{
Eduardo Vinicius Mendes Roncada ${ }^{1}$ \\ Mayra Falcão Pereira ${ }^{3}$ \\ Gisele Alborghetti Nai
}

\author{
Marilda Aparecida Milanez Morgado de Abreu² \\ Claúdia Cardoso Macedo de Oliveira ${ }^{4}$ \\ Deusita Fernandes Gandia Soares ${ }^{6}$
}

\begin{abstract}
Calciphylaxis, also known as calcific uremic arteriolopathy, is a severe complication often observed in patients with hyperparathyroidism secondary to chronic renal failure, which occurs mainly in women. It is characterized by ischemic tissue loss secondary to progressive vascular compromise. This is a rare and severe condition and its pathogenesis is unclear. The best treatment is prevention, especially in order to maintain adequate levels of calcium and phosphorus. We describe a case of this disease in a patient with hyperparathyroidism secondary to chronic renal failure who underwent medical treatment, surgical debridement and total skin autografts, with resolution of symptoms after 6 months.

Keywords: Blood vessels; Calcium metabolism disorders; Hyperparathyroidism, secondary; Ischemia; Renal insufficiency, chronic

Resumo: A Calcifilaxia, também conhecida como arteriolopatia urêmica calcificante, é uma complicação freqüentemente observada nos pacientes com hiperparatireoidismo secundário à insuficiência renal crônica, ocorrendo principalmente em mulheres. Caracteriza-se por necrose isquêmica cutânea, de instalação aguda e progressiva, secundária à calcificação de vasos sanguíneos de pequeno ou de médio calibre. Trata-se de uma afecção rara e grave, cuja patogênese é obscura, e o melhor tratamento é a prevenção, especialmente visando manter os níveis adequados de cálcio e de fósforo. Descrevese um caso desta moléstia em paciente portadora de hiperparatireoidismo secundário à insuficiência renal crônica, submetida a tratamento clínico, desbridamento cirúrgico e enxertos autólogos de pele total, com resolução completa do quadro após 6 meses.

Palavras-chave: Distúrbios do metabolismo do cálcio; Hiperparatireoidismo secundário; Insuficiência renal crônica; Isquemia; Vasos sanguíneos
\end{abstract}

Received on 22.07.2011.

Approved by the Advisory Board and accepted for publication on 29.09.2011.

* Study carried out at the Dermatology Service, Regional Hospital of Presidente Prudente, University of the West Paulista Region (Hospital Regional de Presidente Prudente - Universidade do Oeste Paulista (HRPP-UNOESTE) - São Paulo (SP), Brazil.

Financial Support: None

Conflict of Interests: None

Assistant Professor, Dermatology Service of the Regional Hospital of Presidente Prudente, University of the West Paulista Region (Hospital Regional de Presidente Prudente - Universidade do Oeste Paulista (HRPP-UNOESTE) - São Paulo (SP), Brazil.

Master degree and PhD in Dermatology - Head of the Dermatology Service of the Regional Hospital of Presidente Prudente, University of the West Paulista Region (Hospital Regional de Presidente Prudente - Universidade do Oeste Paulista (HRPP-UNOESTE) - São Paulo (SP), Brazil.

Dermatologist - Private practice - São José dos Campos (SP), Brazil.

Doctor - Specialized in Dermatology at the Universidade do Oeste Paulista (Universidade do Oeste Paulista - UNOESTE) - Dermatology Service of the Regional Hospital of Presidente Prudente, University of the West Paulista Region (Hospital Regional de Presidente Prudente - Universidade do Oeste Paulista (HRPPUNOESTE) - São Paulo (SP), Brazil.

PhD in Pathology from the State Paulista University (Universidade Estadual Paulista - UNESP) - Professor at the Pathology Department, University of the West Paulista Region (Universidade do Oeste Paulista - UNOESTE) - São Paulo (SP), Brazil.

Specialized in Dermatology at the School of Medicine of São José do Rio Pardo (Faculdade de Medicina de São José do Rio Preto - FAMERP) - Assistant Professor at the Dermatology Service, Regional Hospital of Presidente Prudente, University of the West Paulista Region (Hospital Regional de Presidente Prudente Universidade do Oeste Paulista (HRPP-UNOESTE) - São Paulo (SP), Brazil.. 


\section{INTRODUCTION}

Calciphylaxis, also called calcific uremic arteriolopathy (CUA), was first described by Selye in 1962. Its incidence is estimated at $1 \%$ a year in up to $4 \%$ of dialysis patients, especially women. ${ }^{2,3}$

CUA is a panniculitis associated with subcutaneous calcinosis, possibly multifactorial, but whose etiology remains unclear. ${ }^{4,5}$ The diagnosis is confirmed by histopathological examination of a skin biopsy. Calcification and obstruction of small or medium size cutaneous blood vessels can occur, with hyperplasia of the tunica intima and tunica media, septal and/or lobular subcutaneous tissue necrosis, resulting in distal ischemia and painful ulcers, which can lead to gangrene and amputation of extremities. ${ }^{3,6,7}$

It is seen in patients with chronic renal failure (CRF), mainly the ones who are undergoing dialysis or pre-dialisys. ${ }^{2,3}$ The hyperparathyroidism (HPT) secondary to nephropathy is the major cause of CUA, especially when the product calcium $(\mathrm{Ca}) \mathrm{x}$ phosphorus $(\mathrm{P})$ is above $70 \mathrm{mg}^{2} / \mathrm{dL} .{ }^{3,8}$ However, CUA also affects renal transplant patients, seropositive for human immunodeficiency virus (HIV), patients with primary HPT or alcoholic cirrhosis. ${ }^{79}$ Vasculitis, systemic lupus erythematosus, antiphospholipid antibody syndrome and Henoch-Schoenlein purpura are conditions that must be ruled out. ${ }^{5,7,10}$

CUA recognition and early treatment prevent skin necrosis and fatal systemic changes. ${ }^{10}$ However, there is no consensus on the best treatment to be used. ${ }^{8}$ We report here a successful case of this rare disease.

\section{CASE REPORT}

A 62-year-old white woman, retired, born and raised in Presidente Prudente, SP, had been complaining of leg ulcers for 4 years. She developed livedoid spots, erythematous-violaceous plaques and painful subcutaneous nodules located on the distal legs. These progressed to necrosis, causing ulcers between 1 and $7 \mathrm{~cm}$, with irregular borders, erythematous-violaceous edges and granulation tissue covering the bottom, with purulent discharge (Figure 1). She had hypertension, heart disease, obesity and CRF. not on dialysis due to diabetes mellitus type II. Laboratory tests revealed elevated canalicular enzymes, albumin and PTH (Table 1). Plain radiographs of the left leg showed irregularity of the soft tissue and vascular calcification in the medial-distal region to the level of the foot (Figure 2). Histopathology showed hyperplastic and perpendicular capillaries in the superficial dermis, extending to the epidermis, mild lymphocytic infiltrate with intermingled melanophages, and also calcification in the vascular wall of the reticular dermis and subcutaneous tissue, most evident by Von
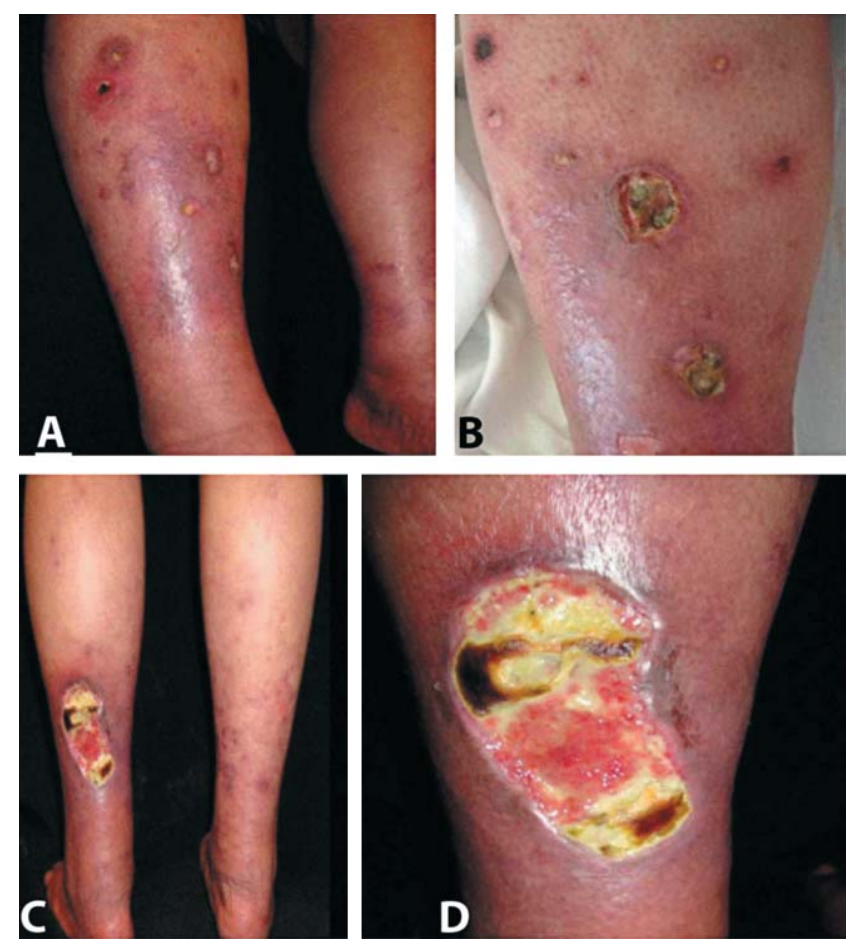

FigURE 1: A and B. Violet spots, erythematous plaques and leg ulcers; C. Extensive ulceration in the posterior left leg, D. Details of the ulcer

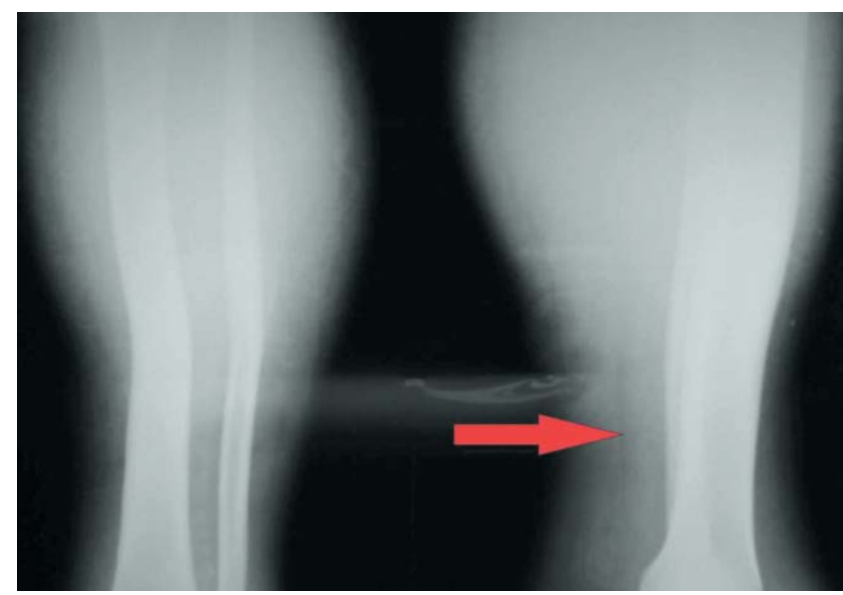

Figure 2: Plain legs X-ray: irregularity of the soft tissues in the $1 / 3$ distal and vascular calcification in the medial-distal left leg down to the foot (arrow)

Kossa staining (Figures 3, 4). Stains for fungi, acid-fast bacilli and spirochetes as well as culture for bacteria and fungi were negative. Diagnosis: Calciphylaxis.

The patient was treated with hypophosphatemic diet, oral replacement of calcitriol $0.5 \mathrm{mcg} / \mathrm{day}$, analgesia, surgical debridement of necrotic tissues and occlusive dressings with $1 \%$ papain and $1 \%$ chloramphenicol. After reducing the levels of parathyroid hormone and serum P, two total skin autografts were made, leading to complete healing of ulcers within 6 
TABLE 1: Laboratory tests

\begin{tabular}{lll}
\hline & Valores encontrados & Valores de referência \\
\hline Clearance de creatinina & $32 \mathrm{ml} / \mathrm{kg} / 1,73 \mathrm{~m} 2$ & $97 \mathrm{a} 137 \mathrm{ml} / \mathrm{Kg} / 1,73 \mathrm{~m} 2$ \\
Proteinúria de 24 hs & $629 \mathrm{mg} / 24 \mathrm{~h}$ & $28 \mathrm{a} 141 \mathrm{mg} / 24 \mathrm{~h}$ \\
Fosfatase alcalina & $418 \mathrm{U} / \mathrm{L}$ & $27 \mathrm{a} 100 \mathrm{U} / \mathrm{L}$ \\
Gama GT & $631 \mathrm{U} / \mathrm{L}$ & $5 \mathrm{a} 27 \mathrm{U} / \mathrm{L}$ \\
Albumina & $2,7 \mathrm{~g} / \mathrm{dL}$ & $3,5 \mathrm{a} 4,8 / \mathrm{dL}$ \\
Ca sérico & $9,0 \mathrm{mg} / \mathrm{dL}$ & $8,6 \mathrm{a} 10,3 \mathrm{mg} / \mathrm{dL}$ \\
P sérico & $5,62 \mathrm{mg} / \mathrm{dL}$ & $2,5 \mathrm{a} 4,8 \mathrm{mg} / \mathrm{dL}$ \\
Paratormônio & $93 \mathrm{pg} / \mathrm{ml}$ & $4 \mathrm{a} 58 \mathrm{pg} / \mathrm{ml}$ \\
VDRL, FTA-Abs, Anti-HIV 1 e 2 & Não reagentes & $\mathrm{Não} \mathrm{reagentes}$ \\
FAN & Negativo & Negativo \\
Anticorpos anticardiolipina e anticoagulante lúpico & Negativos & Negativos \\
\hline
\end{tabular}

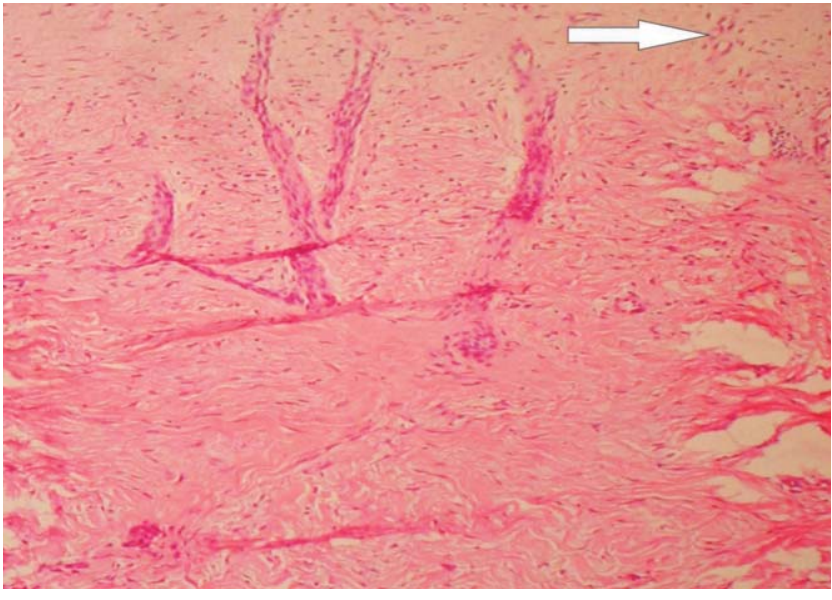

FiguRE 3: Superficial and middle dermis with perpendicular vessels, discrete lymphocytic infiltrate and melanophages (arrows). HE; $40 \mathrm{X}$

months (Figure 5). The patient's HPT is controlled and after one year of follow up the skin lesions have not reappeared.

\section{DISCUSSION}

In the past, it was believed that the metabolic changes of Ca, P and PTH were the only factors which caused CUA. ${ }^{3,4}$ The increase of $\mathrm{P}$ and Cax $\mathrm{P}$ was reported. However, a deficit of calcitriol and abnormalities in the Ca and vitamin $\mathrm{D}$ receptors, observed in CRF with HPT seem to be the factors which trigger the hyper secretion of PTH. ${ }^{2,3}$ In advanced nephropathy, hyperphosphatemia occurs, becoming the major aggravating factor of both HPT and CUA. ${ }^{7,8}$

However, cases of CUA in the presence of normal or slightly altered levels of PTH, Ca and P have been reported. ${ }^{5,10}$ About $70 \%$ of the patients suffering from CUA have serum $P>5 \mathrm{mg} / \mathrm{dL}^{5}$; serum Ca $>10.5$ $\mathrm{mg} / \mathrm{dL}$ is found in $20 \%$; and $33 \%$ of them present product Ca $\times \mathrm{P}>70 \mathrm{mg}^{2} / \mathrm{dL}^{2}$, showing that there is not only one determinant factor which causes this disease. ${ }^{5,10}$ Thus, other conditions contribute to the development of CUA, such as obesity, rapid weight loss, diabetes mellitus, hypoalbuminemia, protein $\mathrm{C}$ and/or $\mathrm{S}$ deficiency, the use of heparin, insulin or iron, trauma, prolonged systemic corticosteroid therapy, immunosuppression and metabolic alkalosis post hemodyalisis. ${ }^{9}$ CUA rarely occurs in patients with normal renal function, in which cases it is important to rule out breast cancer, cholangiocarcinoma, multiple myeloma, severe liver disease and primary HPT. ${ }^{10}$

CUA has poor prognosis, with a mortality rate

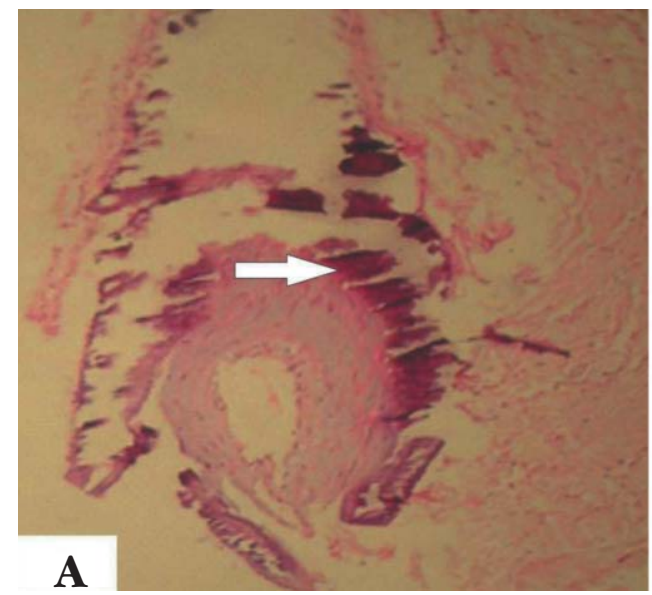

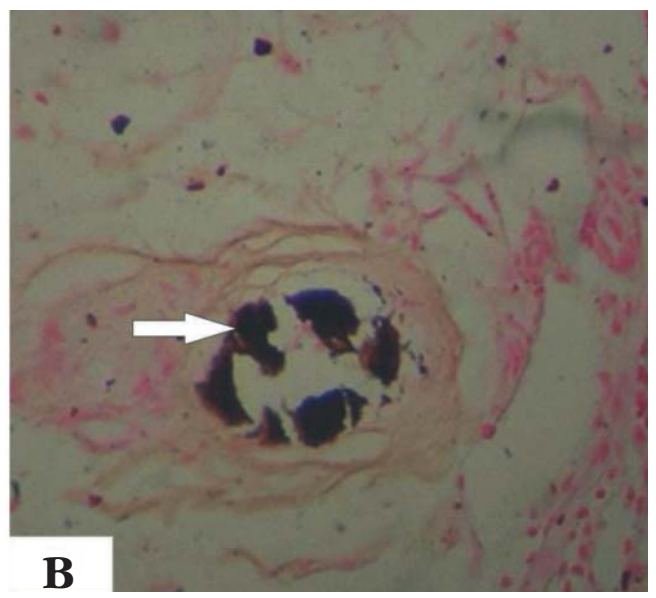

Figure 4: Vessels in the deep dermis with wall calcification (arrow). HE; 100x; Detail of subcutaneous vessel wall with calcification (arrow).

Von Kossa; 400x 


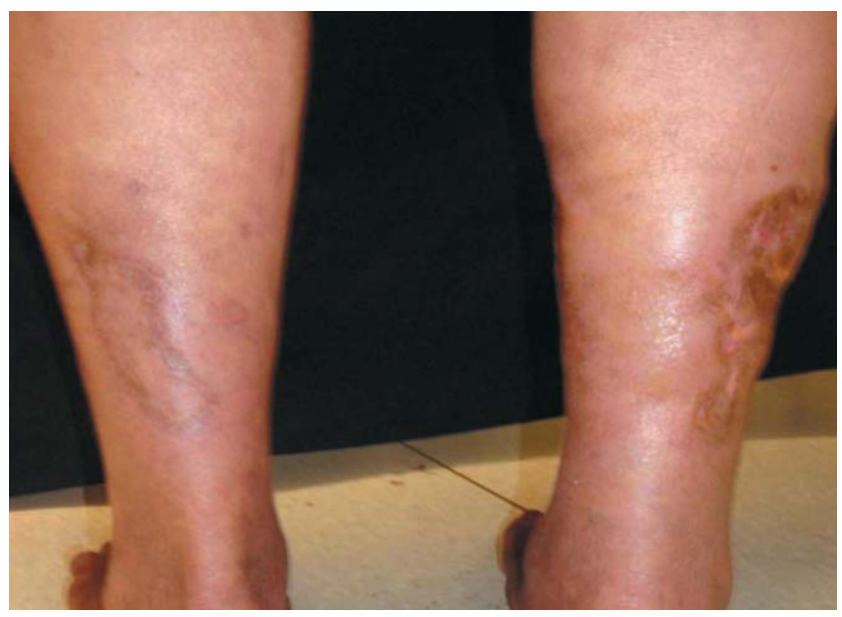

FIGURE 5: Six months after starting treatment: complete healing of ulcers

that reaches up to $80 \%$. Septicemia is the main reason for death, mostly in the first 10 months after the diagnosis. ${ }^{5,9}$ Complications resulting from ischemia and systemic calcinosis include: acute myocardial infarction, stroke, mesenteric ischemia, peripheral arterial obstructions, dementia and sensitive polyneuropathy. ${ }^{6}$ The correction levels of $\mathrm{Ca}, \mathrm{P}$ and PTH are the initial steps of therapy and consequent reduction of morbimortality. ${ }^{8,9,10}$

Aiming at the homeostasis of $\mathrm{Ca} / \mathrm{P}$ metabolism, a hypophosphatemic diet ( $<800 \mathrm{mg} /$ day) is adopted, which is obtained by controlled ingestion of proteins; ${ }^{4,8}$ Ca-free $\mathrm{P}$ chelators so as not to increase the $\mathrm{Ca} / \mathrm{P}$ product; calcium carbonate is contraindicated ${ }^{5}$. Sevelamer hydrochloride appears to have advantage over other chelating agents because it does not induce hypercalcemia. ${ }^{5}$

Wounds that are very painful require analgesia. Non-steroidal anti-inflammatories should be avoided because there is a risk of renal function deterioration ${ }^{4}$ and corticosteroids are not used since they may trigger CUA. ${ }^{5,10}$ Locally, surgical debridement of necrotic areas, occlusive dressing with fibrinolytic agents and antibiotics are other options. ${ }^{8,9}$ The use of hyperbaric oxygen therapy may be another option ${ }^{5}$. Parathyroidectomy is used for refractory cases with serious HPT. ${ }^{4,5}$

In this report, unlike most previously described cases, the patient did not have a $\mathrm{Ca} \times \mathrm{P}$ product very high (approximately $50 \mathrm{mg} / \mathrm{dL}$ ), PTH and serum calcium levels were not so important and pre-dialysis. Other risk factors such as obesity, diabetes and hypoalbuminemia contributed to the development of the AUC. The normal results of laboratory tests such as VDRL, FTA-Abs, ANA and antiphospholipid antibodies, exclude other contemplated diagnoses. The absence of clinical signs of peripheral arterial disease added to normal ultrasound findings (Duplex Scan) of the lower limbs eliminated the possibility of arteriosclerosis with calcification in the arteries.

A Ca $\times$ P product above 45, as in our case, is enough to precipitate calcium phosphate in the blood vessels resulting in calcification, obstruction and hyperplasia of intimal and medial layers, and consequently necrosis of subcutaneous tissue and formation of ulcers. ${ }^{3,10}$ This justifies resetting the calcitriol which is not synthesized by chronic renal failure patients. Skin grafts are helpful in healing, but they are only valid after the patient reaches metabolic balance. In a literature review on the databases from 1997 to 2010 made by Lilacs and Medline there were rare reports of successful treatment similar to the one described here.

It is important to emphasize that preventive measures reduce the risk of CUA in patients with CRF; furthermore, early diagnosis and treatment of skin lesions are vital for the patient.

\section{REFERENCES}

1. Selye H. Calciphylaxis. Chicago, IL: University of Chicago Press; 1962. p.37-82.

2. Ivker RA, Woosley J, Briggaman RA. Calciphylaxis in three patients with end stage renal disease. Arch Dermatol. 1995;131:63-8.

3. Bonamigo RR, Mariante JC, Pisani AC, Bakos L. Calcifilaxia e hiperparatireodismo primário. An Bras Dermatol. 1995;70:358-9.

4. Al Beladi Fl. Catastrophic calciphylaxis in a patient with lupus nephritis and recent onset of end-stage renal disease. Saudi J Kidney Dis Transpl. 2010;21:323-7.

5. Jorgetti V. Arteriolopatia urêmica calcificante (calcifilaxia). Boletim Científico [Internet]. 2003 Maio [acesso 07 out 2010]. Disponivel em: http//portal.samaritano.com.br/pt/interna.asp? page $=1$ \&idpagina $=309$.

6. Hafner J, Keusch G, Wahl C, Sauter B, Hürlimann A, von Weizsäcker F, et al. Uremic small artery disease with medial calcification and intimal hypertrophy (socalled calciphylaxis): a complication of chronic renal failure and benefit from parathyroidectomy. J Am Acad Dermatol. 1995;33:954-62.

7. Marron B, Coronel F, López-Bran E, Barrientos A: Calcifilaxia. Una patogenia incierta y un tratamiento controvertido. Nefrología. 2001;21:596-600.

8. Mendonça DU, Lobão RRS, Carvalho AB. Revisäo: Hiperparatitoidismo secundá-

How to cite this article: Roncada EVM, Abreu MAMM, Pereira MF, Oliveira CCM, Nai GA, Gandia DFS. Calciphilaxis, diagnostic and therapeutic challenge: report of a successful case. An Bras Dermatol. 2012;87(5):752-5. 